\title{
The last legions: The "barbarization" of military identity in the Late Roman West
}

\author{
Vedran Bileta
}

Original scientific paper

UDK 355.11(37)

\begin{abstract}
Traditional scholarship has argued that during the fourth and fifth centuries the waning Roman Empire came to rely to a large extent on recruits of foreign, barbarian origin for its defence. Such a pro-barbarian recruitment policy resulted in the weakening and collapse of Roman military capability in the West, and in the fragmentation and disappearance of the Western Roman state. The article re-examines the "barbarization" theory, following models postulated by M. J. Nicasie and Hugh Elton, as well as the recent results of identity studies focusing on the ancient world. By using the concept of the "barbarian" in political, rather than ethnic terms, the article presents the "barbarization" process not as a prime suspect for the empire's fall, but as another way for the Roman state to maximize its resources and bolster its defences.
\end{abstract}

Keywords: Late Roman army; identity in Late Antiquity; "barbarization"; empire studies; frontier studies

Sometime in 460s, a group of soldiers left the town of Batavis (Passau), in the Roman province of Noricum, to fetch payment for their garrison. On their way to Italy, they were ambushed by barbarians and killed. As the Batavian garrison did not receive the necessary funds, they disbanded, leaving the defence of the town in the hands of the local saint, Severinus, who turned to barbarian armed bands for protection (Eug. Vit. Sev. 20). This little vignette from The Life of Saint Severinus by Eugippius is considered as the last written record of a functioning Roman army in the West. The "last legion" described in The Life has little in common with the victorious and conquering army which made Rome an imperial power. Traditional scholarship, led by Ramsay McMullen, blamed the 
process known as "barbarization" for the dismantlement of the Roman military machine. On the basis of written sources, scholars assumed that during the fourth and fifth centuries, the Roman Empire came to largely rely on recruits of foreign, barbarian origin for its defence. As a result, the fifth-century army was believed to have been composed almost exclusively of barbarian recruits. As they were more loyal to their barbarian commanders than to the Roman emperor, the Roman military capability in the West weakened, eventually leading to the disappearance of the Roman imperial state in the West (Delbrück 1964: 259; Speidel 1994: 81; Sander 1939: 1-34; Jones 1974). ${ }^{1}$ This paper will re-examine this theory, setting forth from the notion of a fluid Roman military identity (or identities) and arguing that the presence of a Germanic element in the Late Roman army did not weaken imperial military capability. ${ }^{2}$ Rather, the paper will argue that the influx of fresh and experienced manpower facilitated imperial survival, and eventually laid the foundations for the core of the military which served the early medieval barbarian rulers. ${ }^{3}$

1 For a detailed discussion of the "barbarization" the Late Roman army, see MacMullen 1988: 176-178. All of these scholars believed that the Roman army was essentially Germanic in character. MacMullen: "[T]he men credited with victory in one engagement after another from 312 on, came outside the Empire; Celts, Germans, Huns, Saracens and Goths. No general wanted...Romans. By the mid-fourth century the typical fighting force...appears to have been half imported. A generation later, imported soldiers formed the majority." See MacMullen 1988: 176. According to Ladner, the phenomenon was so well-known that references are unnecessary (!). See Ladner 1976: 8.

2 As in the modern world, the Late Roman identities portrayed here were multifarious in nature, in a constant state of flux and development, and moulded and revised by a dominant group. For more on the notion of a fluid identity (identities), see Woodward: 1997. For the fluidity of identities in the Late Roman world, see the bibliography in R. Miles 1999. However, most of it pertains to religious identity. For the general concept of Late Roman identity, see Brown, 1972 and Brown 1992. For the Late Roman West, the focus was on the creation of new identities in the aftermath of barbarian invasions. See: Mathisen and Shanzer 2011.

3 It would be wrong to apply a "positivist approach" to the process of "barbarization". The influx of barbarian recruits starting in the third century affected the Roman military structure at all levels. This article aims to demonstrate that the "barbarization" process should be seen within a separate discourse of changing Roman military identities (from the first century onward), as the army based in the periphery created its own identities, which differed from the traditional identities represented by the Empire's core territories. 


\section{Ties that bind: In search of the Late Roman military man}

As this article will focus on the "barbarian" element in the army, a short discussion of the interplay between the Roman/barbarian identities within the Roman army will be necessary. The Late Roman army was an immense organization, with around 400,000 men under arms in the fourth century (Elton 1998:192). ${ }^{4}$ Reading the late fourth-century document known as the Notitia Dignitatum, one can learn that while unit sizes did become smaller, there were more units, widespread along the imperial limites (Seeck 1876; Hoffman 1969; Kulikowski 2000). ${ }^{5}$ Its sheer size and its unique position in the imperial system made the Roman army an important element in the social construction of the Roman identities. ${ }^{6}$ Due to the nature of "Romanization", for an individual or a community becoming Roman was not achieved by forced assimilation, but rather through a remarkably flexible cultural system that was unthreatened by the persistence of distinctively local customs and conventions, but which had a great capability to assimilate foreigners while at the same time facilitating the reception of foreign cultures. ${ }^{7}$ The flexibility of the cultural system meant that the Romans did not lead a one-sided discussion with outsiders, rather it made it possible for the other side to join - in the words of Greg Woolf - "the insider's debate", allowing for the preservation of specific identities (Woolf 2000: 11). ${ }^{8}$

4 Jones established a number of ca. 600,000 men under arms for entire Roman Empire. See Jones 1974: 683. However, recent studies have ascertained that this figure is exaggerated, and based on new evidence Elton's estimate is ca. 410,000 for the entire Empire.

${ }^{5}$ For the most recent work on the subject, see Kulikowski 2000: 358-377.

${ }^{6}$ For impact of the Roman army in the early and high imperial period, see de Blois and Lo Casco 2007. See also R. Alston 1999: 175-195. For the interplay between military and society in the Late Roman Empire, see, Lee 2007: 147-163.

7 Traditional scholarship does argue for the existence of a "Roman" identity or "Roman" culture, which was imposed gradually through a process of Romanization, with Romans (and the Roman army in particular) as its main driving force. Ando 2000: 19-48. The concept of forced assimilation has been discarded by the concept of a flexible system of "Romanization" that required close cooperation from both sides. For the most recent interpretation, see Stouraitis 2014: 179. See also the footnote below.

8 "Becoming Roman was not a matter of acquiring a ready-made cultural package, then, so much as joining the insider's debate about what that package did or ought to consist at that particular time." Thus, the Roman system should not be seen as a static one, but rather as the result of interaction between individual peoples and groups living together, both the "Romans" and "foreigners", who shaped it over time. 
The palpably multiethnic character of the Late Roman army facilitated any soldier's integration into the imperial system. As any other layer of identity, "Roman" ethnicity should be seen as a rather fluid and dynamic concept, which could allow for a considerable degree of flexibility, resulting in the simultaneous existence of multiple identities that could change depending on circumstances (Amory 1997: 14). ${ }^{9}$ Descent clearly did not determine political allegiance, and ethnicity did not play a large role in establishing "Romanness". ${ }^{10}$ The extension of citizenship in 212 AD further facilitated the integration of foreign populations into the Roman world in the fourth and fifth centuries, blurring the differences between "barbarian" soldiers and the traditional aristocracy (Matthisen 2006a: 1014-1015). ${ }^{11}$ Flavius Stilicho's citizenship is specifically mentioned by his panegyrist Claudian, although one cannot state with certainty how precisely his citizenship was obtained (Claud. De cons. Stil. 3.180-181). ${ }^{12}$ The sharp division between the military and civilian offices following developments in the third century, as well as the redefinition of the Roman manly ideal, only further obscured the distinction between "barbarian" and Roman. ${ }^{13}$ Imperial service,

9 Ethnicity, as Patrick Amory puts it, is essentially a definition of the group "usually on the basis of its belief in common descent and a shared past".

10 However, the fact that ethnicity did not play a primary role in the (self) definition of Late Roman individuals does not mean that it did not matter. For diminishment of one's origin as a factor in establishing the Late Roman identity, see Elton 1996: 100. Cf. Pohl 1998: 18.

11 According to Mathisen, this layer of identity, often underplayed in scholarship, continued to play an important role in defining a personal and legal identity after 212 . He argued that the Antonine Constitution did not put an end to the distinctions of citizen/peregrinus status. It rather refined its role, encompassing various manifestations of citizenship - civic, provincial, religious and ethnic - that in turn created a number of different sub-identities, legal and personal, which could interact in different ways. It also changed the relationship between empire and its citizens. After Roman citizenship became universal, the generic term cives did not denote "Roman citizens", but "citizens of cities". For source evidence, see: Amm.[=Ammianus Marcellinus] 9.2.14; 27.3; 27.9 .9 (for cives Romani as citizens of Rome, not of an empire). See also CTh[=Codex Theodosianus] 1.29.6 (387). For a different idea on Late Roman citizenship, see Brown 1992: 154.

12 "Rome rejoiced that she deserved to have you as citizen". Perhaps Claud.[=Claudian], De cons. Stil. 3.152-153 is also more revealing of the army's role in obtaining citizenship: "She calls together as citizens those whom she had conquered". For the issue of granting citizenship to barbarians in the Late Roman empire see Mathisen 2006a: 1020-1026.

13 For instance, the law of 364 explicitly forbids civilians from bearing arms, leaving it as a prerogative for the military. CTh, 15.15 (364). 
including service in the army, came to be a new vehicle for an individual to present himself as a proper "Roman". The visibility and distinction of the army from the civic sphere was further enhanced by the former's distinctive, ceremonial, dress and privileges (Coulston 2010: 463-492; Coulston 2004: 135152). ${ }^{14}$ The military aristocracy intermarried with both the imperial family and barbarian leaders, to the extent that the conduct and culture of this type of elite cannot be categorized by traditional Roman/non-Roman ethnographic classifications (Whittaker 1994: 243-278). The cosmopolitan and meritocratic nature of the Roman army allowed the "barbarian" to blend in, unrelated to his origin or pre-military social status, and to ascend to the higher rungs of the imperial administration's ladder by relying only on his accomplishments and skills. Nevertheless, in a society as complex as that the Roman Empire in its waning years, his "barbaric" origin would not be easily forgotten. ${ }^{15}$

\section{Through the eye of the beholder: "miles" et "barbarus"}

The "barbarian" recruits manned the army in large numbers and shed blood for the Empire. However, the Roman civilian elite continued to look upon the "barbarians" through the smoked glass of Graeco-Roman tradition. To better understand the nature of the problem, and to clarify its representation, it is perhaps more useful to think in terms of what the "barbarian" as a literary construct meant to late Roman author vis-à-vis their attitudes toward their own

14 For one of the most important visible and aural elements in the Late Roman environment, the military belt, which denoted its owner as a military man, see Hoss 2011: 29-44).

15 The soldier's isolation from the educated civilian circles and his warrior pedigree could serve as a powerful device, as a link to an emperor of military origin or as a connection with other military officers of non-Roman stock. Furthermore, some facets of barbarian identity could be employed when competing with non-military elites of the Late Empire. Thus, we see imperial barbarian commanders using their office bestowed by the emperor to promote themselves both within the empire, as high ranking military (and political) leaders, and at the same time travelling back to non-imperial territory, where Roman status assured them a high place in "barbarian" society. Such is the case with Vadomarius, king of the Alamanni, Gabinius, king of the Quadi, and Macrianus, also a king of the Alamanni. They all used Roman aid to reinforce their power in the barbaricum. See, respectively: Amm. 21.4.3; 29.6.5; 18.2.17. See also, Lee 1993: 71. However, it was not easy for a "barbarian" general to maintain his high status in both the Empire and the "barbaricum". As Ammianus tells us, when blamed for usurpation against his emperor, Silvanus briefly contemplated escaping to his own people, but decided against it, after he received notice that his own fellow-countrymen would kill him, or turn him over to the emperor. Amm. 15.5.6. 
identities. Roman depictions of barbarians are not part of the dialogue between "us and them", but "us and us", between Romans (Halsall 2007: 56). As Peter Heather pointed out, in the fourth century "it is no surprise therefore that the more precise connotations of the image of the barbarian, as it had evolved by late antiquity, served to underline what was good and important about being Roman" (Heather 1999: 235-236). Roman politics also thrived on the traditionally negative image of a "barbarian". The barbarian creature was there, out in the open, not only to be juxtaposed with a "good Roman", but also to show the continuing supremacy of the imperial Roman state, as victories over barbarians did help to preserve the internal stability of the empire, and increase the emperor's prestige (Heather 1999: 236). ${ }^{16}$ No imperial victory was complete without its supporting cast of subservient barbarians. ${ }^{17}$

However, by the fourth century, the gap between that idealized mirror image of a docile, uncivilized and weak barbarian and reality became even wider. The "simple" Germani of Tacitus were replaced by formidable political entities with coherent social hierarchies, with no small Roman agency involved (Whittaker 1994; Heather 1996: 51-95; Elton 1998: 15-89). That inferred a varied and much more subtle foreign policy, based on negotiation with barbarian client kingdoms, rather than the policy of total cultural and military domination usually presented by imperial propaganda. ${ }^{18}$ The break with the idealized image of the barbarian arch-enemy was particularly striking when Romans and barbarians fought other Romans - during the civil wars, which were commonplace in the fourth century. As J. Conant put it: "Legitimacy, like beauty, is in the eye of the beholder" (Conant 2012: 19). The Late Roman army made use of barbarian contingents and employed their warlike qualities to strengthen its frontier forces. But for the purposes of imperial propaganda, the use of barbarians proved to be

\footnotetext{
16 "There is in each of us a barbarian tribe, extremely overbearing and intractable - I mean temper and those insatiable desires, which stand opposed to rationality as Scythians and Germans do to the Romans". See also Them.[=Themistius]. Or.10.131b-c. For barbarians as a vehicle in imperial propaganda, see Mathisen 2006b: 27-35. See also Heather 1999: 235-236.

17 For a good discussion of the barbarian role in imperial ideology, see McCormick 1986: 11-120.

18 The Roman army of the fourth century could still embark upon raids or punitive expeditions into barbarian territory (as in the case of the Emperor Valens' campaign against the Goths) but those incursions had more limited aims, and were conducted on a smaller scale than its Principate predecessor. For Valens' punitive expedition against the Thervingi (367-369), see Lenski 2006: 127-137.
} 
an extremely useful way to discredit the defeated opponent. As "barbarians" were unable to live under the law, anyone who (in eyes of the imperial government) refused to live according to the law (brigands, bandits) was assimilated into the barbarian category. This could also be applied to any unrecognized authority. As the imperial government was the only proper ruling body, the (failed) usurpers and rebels were branded barbarians (Halsall 2007: 55). A good example is the rebellion of Firmus in Africa, whose followers Ammianus labeled barbarian savages. However, prior to the rebellion, while still a part of the imperial system, Firmus was portrayed through a decidedly Roman lens (Amm. 29.5.12; 29.5.39; 29.5.41). Following his demise at Frigidus in 394, Eugenius was branded a "barbarian" and usurper due to his connection to the Roman general Arbogast, who was of Frankish origin. The winner of the struggle, Theodosius, was presented as a proper emperor; even if he had a large contingent of Goths fighting on his side (Pac. 32.3-4). ${ }^{19}$ The infamous purges against barbarians in the late fourth and fifth century should be seen in a similar context. There may be some degree of animosity present in the attacks. But, as Elton pointed out, the attack on Gainas' Goths in Constantinople (378) or on Stilicho's men in Ravenna (408) should be seen less as a result of widespread antibarbarian sentiment, and more as a consequence of the defeat of the leaders and patrons in the Roman political arena. ${ }^{20}$

There is one more aspect of identity to consider, that of region and profession. The army, due to its location on the imperial periphery (along limites) formed its own, distinctive identities, which were gradually appropriated through the entire frontier zone. As the grasp of the centralizing and homogenizing imperial ideology weakened in the West, the distinction between "army" and "barbarian" became increasingly blurred, both rhetorically and in reality. In the late Empire, within frontier regions - always important recruiting grounds -

19 Thus, it was not one's origin but rather the act of rebellion against the established order which could drive one out of the Roman world and accord the category of the "other" to him. Here, I would like to invoke Shaw's image of the Roman brigand as a man of violence operating outside of these controls, a phenomenon created by "the shifting frontiers of the definition of authority within the state itself". Shaw 1984: 3-52.

20 The downfall of the military men of Gothic origin should then be seen as a consequence of their involvement in what was perceived by the government as a dubious activity. See Elton 1998: 142-145. One can make comparisons with the prominence of Pannonians under Valens and Valentinian, Spaniards under Theodosius, or Aquitanians under Gratian. For Pannonians see Matthews 1975: 35-39; for Aquitanians (Gaul), 6977, and Spaniards, 94-96. 
"Roman soldiers" became scarcely distinguishable from "barbarian soldiers". The words peregrini, and alieni, traditionally used to describe barbarians, now described "Romans" who lived on the limes (Nov. Theod. 4). ${ }^{21}$ On the other hand, barbarus became a generic term for denoting a soldier in addition to miles. ${ }^{22}$ In eyes of civilian elites - who had shifted their battles to the bodily plane - the martial culture and aggressive nature of soldiers and their inability to control their bodies made them potential threats to the "civilized" parts of the Empire, in other words, "barbarians". ${ }^{23}$ Furthermore, certain military elements, such as elaborate military finery, particularly ornamentation, became associated with what was perceived as a barbarian custom. ${ }^{24}$ The lack of terminology differentiating between regular and irregular (or "allied") troops in the fourthand fifth-century Roman army shows the flexibility of Late Roman military identity.

Thus, although one cannot pinpoint the primary "Roman" identity, I would suggest considering Late Roman military identity through the lenses of political identity and identity as dictated by region and profession. What mattered for one to be branded a "Roman" or "barbarian" was not his origin or even citizenship. Rather it was the status of individuals in the Roman imperial state, most of all

21 For more on the concept of professional identity, see Amory: 1997: 26-30.

22 This is particularly apparent in fifth century legal codes: CTh 11.30 .62 (405): appeals by barbari are to be heard by their prefects; CTh 3.14.1 (370): the barbari gentiles whom the provincials of Thrace were forbidden to marry were clearly soldiers. Alaric's troops are foederati when fighting on behalf of the emperor, barbari when rebelling against him: CTh 5.7 .2 (408); 7.16 .2 (410); 10.10 .25 (435); 15.14 .14 (416). A Greek papyrus document from fourth century Egypt contains a letter (34) in which a mother complains that her son has been sent "among the barbarians", meaning "into the army". See Bell 1962: 86-87.

23 In the same period, traditional elites, banned from the military sphere, created their own code of conduct, focused on fighting the internal battles of body-control; and proper comportment. See Conway 2008: 24-31; Cameron 1991: 77-78. For the importance of paideia in the fourth century's Empire, see Gleason 1995: 22-23. Gleason argued that the display of paideia in public, from the second to fifth centuries $A D$ became one of the main denominators of proper manly conduct - not only a display of one's "mastery of words" but also the ability to wield a correct manly voice, keep emotions under control and maintain the necessary facial expression and gestures.

24 Barbaricaria in Not. Dig. Occ. 11.74-77. Not. Or. 11.45. It is possible that use of barbarica was reserved for elite troops, auxilia palatina. See Rocco 2012: 328-329. See also CTh 10.22 .1 (410) for the profession of barbaricarius; maker of cloth with gold or silver threads (goldsmith?). 
loyalty to the emperor and the court, and perception of them by the educated senatorial elite.

\section{"Barbarization" or "Romanization"}

The flexibility and inclusiveness of Roman military identity facilitated the absorption of barbarian recruits into its ranks. This large influx of barbarians led some scholars to believe, as mentioned at the beginning of the text, that "barbarization" was one of the major causes of the imperial downfall in the West. In the next few paragraphs, I will re-examine the "barbarization" theory, following models postulated by Nicasie and Elton, and place them within the framework of Late Roman military identity. The analysis will focus on four most contested aspects: the origin of military commanders and their subordinates, the ethnic composition of military units, the presence of "barbarian" customs in the army, and the impact of "barbarization" on the army's efficiency. Finally, following the theory proposed by P. Amory, a notion of military conscious "takeover" of the "barbarian" identity, to be used in stark opposition with civilians, will be explored.

As established, soldiers of barbarian origin had indeed formed a considerable part of the Late Roman army. Unlike the proponents of "barbarization", Nicasie and Elton saw a problem in identifying the barbarian element in the Roman army by their names (Elton 1996: 141-143; Nicasie 1998: 98). What remains is then the study of personal and family names. This is not a simple endeavour, as the geographical provenance of names is difficult to establish. Most of the military men in Late Antiquity came from rural areas, and were of a humble origin and could continue using their own non-Roman names. On the other hand, what appears to be a traditional Roman name may actually be the name of a Romanized barbarian. ${ }^{25}$ The work of Ammianus Marcellinus is full of such examples, featuring fully Romanized generals who had little or nothing to do with their former compatriots on the other side of the border. Roman generals Bonitus and Silvanus (father and son) were actually of Frankish

\footnotetext{
${ }^{25}$ However, there is one place which can shed some light on the problem. Of the thirtynine names pertaining to twenty three different military units (most of them comitatenses) at a military cemetery near Aquileia, fourteen can be considered Germanic or Gothic in origin, such as Flavius Fandigildis and Flavius Sindila. See Hoffmann 1963: 22-57. Further, as most of those inscriptions can be dated to 394 or 395 , it is likely that "barbarization" did not affect the imperial military structures in the years following the battle of Adrianople. See also Nicasie 1998: 105-107.
} 
origin (Amm. 15.5.33). Flavius Stilicho, a powerful general and politician, was disdained by the traditional Roman nobility because of his Vandal origin. One of the leading intellectual figures of that time, Jerome, called him semibarbarus (Elton 1996: 141-142). But, as Elton argued, Stilicho should be regarded more Roman than any of his opponents for the very reason that it is thanks to him and not the conservative and ineffective Roman senate - that the Roman state endured for a few more years (Elton 1996: 141-142). ${ }^{26}$ Fravitta, Stilicho's contemporary, was a general of Gothic origin, described by Zosimus as "by birth a barbarian, but otherwise a Greek, not only in habit but also in character and religion" (Zos. Hist. Nov. 5.20). Even the father of the "last Roman" Aetius, Gaudentius, was probably of Gothic origin. ${ }^{27}$ So, as Elton pointed out, relying on names alone is insufficient and faulty. Further, there is the problem of the lower ranks and common soldiers. The period considered here, i.e. the fourth to fifth century, shows a sharp decrease in the number of inscriptions, making it difficult to draw any conclusions. Most of the soldiers were simple, semi-literate or illiterate peasants, leaving no written evidence at all. But is it Elton's second conclusion that matters: that the proportion of non-Roman officers within the army did not increase over the given period (350s-470s) (Elton 1996: 145-152). ${ }^{28}$

There is also the problem of unit identity, which traditional historiography denotes as "barbarian". The lack of source material makes it virtually impossible for a researcher to establish the ethnic composition of Late Roman units. The barbarian name of the unit in the Notitia Dignitatum does not necessarily mean

\footnotetext{
${ }^{26}$ For instance, Rutilus Namatianus, known for his negative attitude to barbarians, "makes no mention of his origin in a posthumous torrent of invective describing Stilicho as a traitor to the empire by letting in the barbarians." For more on Stilicho, see "Stilicho", PLRE [Prosopography of the Later Roman Empire] I.

${ }^{27}$ Flavius Gaudentius, PLRE II, 495.

${ }^{28}$ Elton's first conclusion was that less than one-third of the army officers were actually barbarian in origin. In his analysis of known names, out of 100 officers who had both Roman names and a stated ethnic or geographic origin, only eight were barbarians. Elton acknowledged that there may be a problem in his analysis, as there is a discrepancy between the number of barbarians holding the high office of the magister militum (higher than the average) and lower ranking officers. If this is the result of better evidence for higher ranks then perhaps the proportion of barbarians may have been higher. Nicasie similarly argued for a low number of barbarian officers in the imperial ranks. In the period under consideration (342-395), approximately a quarter of the known names are found to be of Germanic stock. Nicasie argued that at least until the battle of Adrianople more than seventy percent of the generals were of Roman origin. See Nicasie 1998: 102-103 See also Lee 2007: 84-85.
} 
that it was comprised exclusively, or even largely, of barbarian recruits. ${ }^{29}$ Units with foreign names, raised from single tribes may over time have become more heterogeneous as locally trained recruits filled the gaps caused by death and retirement (Nicasie 1998: 99; Hoffman 1969: 135). ${ }^{30}$ Moreover, it is possible that some units retained their barbarian names because of some particular significance accorded to them. Such is the case of palatine auxiliary units (elite troops) with "ancient" ethnic names such as Cimbri, Celtae or Sabini. ${ }^{31}$ The relationship between the connotation and unit's name is further proven by names that some elite palatine units took, which stressed animalistic or warlike qualities disdained by civilian elites (Cornuti, Leones, Feroces or Victores). ${ }^{32}$ It is possible that those units appropriated such names to stress their own warlike character and strength while at the same time developing an alternative to traditional civilian masculinity.

Previous scholarship used evidence on barbarian customs in the Roman army as one of the main arguments for the ongoing process of "barbarization". ${ }^{33}$ Some of the more notable examples are the Germanic war cry - barritus, the raising of the elected emperor on a shield - Schilderhebung, and the adoption of supposedly Germanic battle formations such as the wedge - cuneus or caput porci. ${ }^{34}$ However, as Nicasie pointed out, it is very difficult to prove that the

${ }^{29}$ For instance, one can find in the sources evidence for the existence of a "regiment of Heruls", a "regiment of Batavians", etc. Heruli seniores: ILCV 464, 548; numerous Batavorum seniorum: ILCV 460, 480-1, 499., Batavi Seniores Not. Dig. Occ. 5.163=7.14, Or. 5.49.

${ }^{30}$ For instance, the eighth squadron of Vandals consisted of almost entirely Vandals in the fourth century, but by the fifth it only consisted of Roman provincials, Lee 2007: 84-5.

31 Sabini: Not. Dig. Occ. 5.195=7.22; Celtae: Not. Dig. Occ. 5.161=7.12, 5.205=7.141.

32 Not. Dig. Occ. 5-6. However, as Nicasie has stated, only twenty-three auxilia palatina bear the names of tribes from beyond the imperial borders, Nicasie 1998: 55. It is noteworthy that the only soldier known by name from the Cornuti, traditionally considered Germanic in nature, is Flavius Aemilianus, a Roman from Dacia. Drew-Bear 1977: 257-275. = AE (1977) 806.

33 For a negative view of the Late Roman infantry (less trained, less disciplined, and less well equipped than its early Roman predecessor), see Sander 1939: 30-31 and Hoffman 1969: 135.

${ }^{34}$ For barritus see Amm. 16.12.43; 26.7.17; 31.7.11. See also Vegetius, 3.18. For the elevation of the emperor on the shield, see Amm. 20.4.17; Zos. 3.9.4. (for Julian's elevation on the shield by the Army of Gaul in 360 AD). For Germanic practices, see Tac. Hist. 4.15. For more on barritus, see Hoffman 1969: 135-137. See also Nicasie, 
customs described in the sources were indeed of barbarian origin and that they can be interpreted as signs of a growing number of barbarians in the Late Roman military. On the contrary, they could be cases of nothing more than the adoption of customs that Romans found useful, as throughout history the Romans adapted what they saw fit for military purposes (Nicasie 1998: 114-115). ${ }^{35}$

Regarding the decrease in combat capability, as a result of the growing number of barbarians in the ranks, one could argue that it is highly questionable that the Late Roman army suffered more setbacks or defeats than its counterpart in the early Empire. Even if this was the case, it is impossible to determine whether this was a direct consequence of the army being thoroughly barbarized, or simply due to inadequate leadership or poor fortune. One must not forget that the barbarians bordering the Empire were held in particularly high esteem when providing manpower. It was normally required from barbarians defeated in war to provide recruits for the Roman army (Nicasie 1998: 87-88, n. 31). ${ }^{36}$ Moreover, Romans had a long tradition of hiring foreign soldiers. If the Romans needed more troops, an easy option would be to look beyond the imperial borders. ${ }^{37}$ The third-century crisis, however, led to increased demand for military manpower, particularly for recruitment beyond the frontier (Cameron and Long 1993: 199233; Whitby 2006: 7; Speidel 1975: 203). Besides recruitment of individual barbarians, sometimes entire barbarian tribes were settled in border areas in return for frontier defence. This allowed Roman soldiers to serve elsewhere (Nicasie 1998: 88). However, recruitment itself acted as a powerful agent of "Romanization". Through the induction rituals, such as an imperial oath, and participation in a unit's institutional life, a specific esprit-de-corps was fostered among fellow soldiers. Further incentives, such as regular pay, promises of booty,

Twilight of Empire, 107-116 for a detailed analysis of barbarian customs and formations.

${ }^{35}$ There is another possibility, that of the Roman-barbarian "civilization merging", which is discussed below.

${ }^{36}$ This practice was employed by all the fourth century emperors (Diocletian, Galerius, Constantine, Maxentius, Julian, Constantius II, Valentianian, Gratian, Valens, Theodosius I).

${ }^{37}$ Roman armies always relied on a large number of outsiders, as Germanic recruits were included into the army since the time of the Principate onwards. Besides their military prowess, the impressive stature of blond and tall "non-Roman" guardsmen (equites singulari Augusti) heightened the emperor's splendour and status. See Speidel 2002: 125, 61-79. 
and the possibility of achieving the highest ranks in imperial society only further cemented a soldier's loyalty. ${ }^{38}$

Then why did the Late Roman military require an increased influx of "barbarian" personnel? The older assumption that military service had become increasingly unpopular amongst fourth-century Roman men of all classes has recently been challenged as well (Lee 2007: 84-85). Recent studies argue that the number of deserters from the Roman military in the fourth and fifth centuries was not significantly greater than in earlier periods (Williams and Friell 1998: 211; Lee 2007: 82-83; Williams and Friell 1998:211). The evidence is at best confusing. The selection of texts preserved in the Theodosian Code is generally considered as a whole, but they should be differentiated. The earlier set - the laws dating to the reigns of Valentinian I, Valens and Theodosius I - do leave an impression of coherent management of the recruitment process for the standing army. ${ }^{39}$ The other set contains ad-hoc responses to the specific military crises in the Western part of the empire and does not seem to be applied empire-wide, as was the case with most of the preceding examples. ${ }^{40}$ One can find evidence of desertion in the laws, and of measures employed by the imperial authorities to counter it. ${ }^{41}$ But the laws show the remarkable resilience of the military recruitment system in an

${ }^{38}$ Those who enlisted to the service were granted considerable privileges. After taking the oath, a soldier was exempted from paying the poll tax (capitiatio). Soldiers were given legal and fiscal immunity not only for themselves, but for their families as well. For the immunity given by Constantine I to his comitatenses and ripenses in 325, see CTh 7.20.4 (325). In 370, Valens limited those rights only to soldiers and their wives: CTh 7.13.6 (370). The law was later extended to parents again, but only of comitatenses who had five years of service: CTh 7.13.7.3 (375), see Nicasie 1998: 93-94. See also Southern and Dixon 1996: 68-69.

${ }^{39}$ CTh 7.13.3 (367) Valens and Valentinian I to the vicarius of Rome. The law stipulates that recruits for the army should be at least 5 feet 7 inches tall, which was taller than the average Roman male. Such a rather rigorous stipulation for recruitment suggests that recruitment did not present a problem, at least in the period under consideration. Also see Veg. 1.5.

${ }^{40}$ For actions against those who wanted to avoid military service by cutting off their fingers, see CTh 7.13.4 (367), and 7.13.5 (368? 370? 373?); 7.13 .10 (381). Also see Amm. 15.12.3 Interestingly, Ammianus stated that the practice was endemic for Italy, but alien to the Gauls, which does imply its localized use.

41 "Brands, that is, the official state mark, shall be stamped on the arms of the armourers, in imitation of the practice of branding army recruits, so that in this manner at least it may be possible to recognize skulkers," see CTh, 10.22 .4 (398) For soldiers being tattooed, not branded, see Vegetius 1.8. On deserters, see CTh 7.18.4 (380); 7.18.6 (382); 7.18.9.1 (396); 7.18.14.1(403). 
empire under pressure. The law that encourages the admittance of slaves into the army (406) stands in stark contrast to an edict issued 26 years earlier, which expressly forbids recruitment of slaves, members of disreputable professions or dishonourable occupations, cooks, and bread-makers. ${ }^{42}$

There is one more possibility to consider. P. Amory recently proposed the "conscious barbarization" hypothesis. It seems that during the fourth century, the army began to create its separate, new identities, centred on ethnographic constructions of the non-Roman as opposed to the "Roman" civil bureaucracy (Amory 1997: 26-28; Halsall 2004: 22). As troops in service of the government, they may have felt alien in the provinces, and played upon this, intentionally appropriating barbarian customs, which comported with their military character (Amory 1997: 27-32). The appropriation of the aforementioned warlike qualities and animal imagery by the most elite palatine units could be interpreted as a way to express their special status and unique status in Late Roman society. The "animal" imagery used in naming and depicting the auxilia palatina, as well as some of the elite praesental field army units, could be perceived as a deliberate construct created within the late imperial army as part of the redefinition of Late Roman identities following the separation of military and civil service. The names of Late Roman units are quite different from earlier imperial names, as they stress qualities that are the very antithesis of classically-defined Romanness: animal names, ferocity, and fierceness (also animal qualities). ${ }^{43}$ The boastfulness inherent in these titles, usually reserved for the "barbarian", does constitute a clear difference from normative Romanness, perceived by the educated civic elites. Thus, what is traditionally understood through the derogatory lenses of the "barbarization" of Late Roman military structures should rather be seen as the military adoption of a different discourse of Roman masculinity in a clear opposition to traditional "civic masculinity".

${ }^{42}$ CTh 7.13.16 (406) Cf. CTh 7.13.8 (380). Permission for slave recruitment could be explained by the precarious socio-political conditions in which the Empire found itself at the beginning of the fifth century. In the case of 406 it was the sudden invasion of Radagaisus. Or it may have only been a temporary stopgap measure, prompted by the troublesome situation in Italy only. A similar situation can be traced in 357, during the rebellion of Gildo, when the government requested senators to send their slaves into service. See Jones 1974: 614. The occasional mention of such a law being enacted in times of crisis may imply that the army did not have severe problems with recruitment, at least until the end of the fourth century. Elton 1996: 153-154.

43 For some examples of unit names, see p. 9. 


\section{The end or a new beginning?}

The key to the "barbarization" problem may lie in the period following the disintegration of the Western Roman polity, in the inception of the barbaric kingdoms. In his recent monograph, Petersen argued that the core of the Frankish military was formed from the seasoned remnants of the last legions on the Rhine. Based on an analysis of early Frankish military equipment, tactics, unit structure, and, perhaps most importantly, their knowledge of siege engines, Petersen suggested that the barbarian soldiers in Roman employ, with military experience and know-how, became an attractive option for the barbaric rulers (most of them serving for Rome) following the dissolution of imperial administration in the mid-fifth century. The collapse of the army left them without their high status and command, eliminating the Roman facets of identity, but leaving the Frankish one, which due to the nature of Romanization, was never eliminated (Petersen 2013: 192-255). Furthermore, as the military identities of the Late Roman military men were often in opposition to those of the civilian elites, one may assume that following the dismantlement of the imperial suprastructure, which provided them with salary and status, the border troops on the Rhine found the mentality of the Frankish military aristocracy much more to their liking. Instead of facilitating the destruction of an Empire, the Franks instead repurposed the system, once the imperial supra-structure collapsed.

The "barbarization" process of the fourth and fifth centuries significantly altered the Roman military. The influx of recruits of the foreign origin resulted in a change of tactics, weaponry and even the unit names. As the pressure at the boundaries mounted, and with the recurrence of the civil wars during the given period, the gaps in the army ranks were increasingly filled by the personnel of foreign stock. The process intensified in the fifth century as the traditional commanders-in-chief - the emperors - distanced themselves from their soldiers, opting for the relative security of the walled imperial capital at Ravenna. The role of the supreme military commander was taken over by the men like Stilicho magistri militum - who used their military power base to assume control over the government as well. Although most of the "barbarian" military men were Romanized upon their entry into the service, the traditional enmity of the civilian elites continued, with the status of the military being constantly contested. At the same time, the Roman army appropriated the "barbarian" habitus, attempting to highlight its own, separate identities. The significant losses of imperial territory in the first half of the fifth century further limited military responses, resulting in fragmentation of the Western Roman polity in the late 
fifth century. However, as presented in the text, it is difficult to blame the "barbarization" process for this development. Instead of decline and corruption, the prominence of military men of non-Roman origin in the Roman army should be seen as strong evidence of a flexible Roman society, as another way of the Roman state maximizing its limited resources. The contribution of barbarian soldiers to military manpower and leadership strengthened the empire as a whole and ensured its survival into another century. Due to the nature of the Roman army and the flexibility of Late Roman military identity, the large numbers of foreigners incorporated into its ranks preferred to be Romanized rather than "barbarizing" the army in which they served. It could be argued that the very cultural mélange and continuous development within a single military organization was what made people "Roman" beyond a mere chronological and political epithet, unifying the Empire under the umbrella of the Roman military. Furthermore, if one could inject Petersen's hypothesis into the notion of Late Roman military identity, the demise of the last garrison at Batavis should not be seen as the end of the Roman army in the West, but rather as the seeds of the new military system in the barbarian successor kingdoms.

\section{Bibliography}

Primary Sources

Ammianus Marcellinus, "Res Gestae", in: Ammianus Marcellinus, ed. and tr. John C. Rolfe, Cambridge 1935.

Claudian, in Claudian, ed. and tr. M. Platnauer, London, 1922.

Eugippius, "Vita Sancti Severini. The Life of St Severin," tr. L. Bieler, Washington, DC 1965.

In Praise of Later Roman Emperors. The Panegyrici Latini, ed. and tr. C. E. V. Nixon and B. Saylor Rodgers, Berkeley 1994.

"Notitia dignitatum: accedunt notitia urbis Constantinopolitanae et Latercula Prouinciarum," ed. Otto Seeck, Frankfurt am Main, 1876; repr. Frankfurt, 1962.

The prosopography of the later Roman Empire vol. I and II. A. H. M. Jones; J. R. Martindale and J. Morris, Cambridge 1971.

The Theodosian Code and Novels, and the Sirmondian Constitutions, tr. and ed. C. Pharr, Princeton 1952. 
Themistius, "Orations," in: Politics, Philosophy and Empire in the Fourth Century: Select Orations of Themistius, tr. P. Heather and D. Moncur, Liverpool 2001.

Vegetius, "De Re Militaris: Epitome of Military Science," tr. N. P. Milner, Liverpool 1993.

Zosimus, New History, ed. and tr. R. T. Ridley, Canberra 1982.

\section{Secondary Sources}

\section{AMORY 1997}

Patrick Amory, People and identity in Ostrogothic Italy, 489-554, Cambridge 1997.

\section{CLIFFORD 2000}

Clifford Ando, Imperial ideology and provincial loyalty in the Roman Empire, Berkeley 2000.

BELL 1962

H. Idris Bell, The Abbinaeus archive. Papers of a Roman Officer in the Reign of Constantius II, Oxford 1962.

DE BLOIS AND LO CASCIO 2007

Lukas de Blois, Elio Lo Cascio and O. Hekster (eds.), The impact of the Roman army (200 BC-AD 476), Leiden 2007.

BROWN 1972

Peter Brown, Religion and society in the age of Saint Augustine, New York 1972.

BROWN 1992

Peter Brown, Power and persuasion in late antiquity, Madison 1992.

CAMERON 1991

Averil Cameron, Christianity and the rhetoric of empire, Berkeley 1991.

\section{CAMERON AND LONG 1992}

Alan Cameron, Jacqueline Long, Barbarians and politics at the court of Arcadius, Berkeley 1992.

CONANT 2012

Jonathan Conant, Staying Roman: Conquest and Identity in Africa and the Mediterranean, 439-700, Cambridge 2012.

CONWAY 2008

Colleen M Conway, Behold the Man: Jesus and Greco-Roman Masculinity, Oxford 2008. 


\section{COULSTON 2004}

J. C. N. Coulston, "Military identity and personal self-identity in the Roman army," in: Roman Rule and Civic Life. Local and Regional Perspectives (ed. L. De Ligt), Leiden 2004, 135-152.

\section{COULSTON 2010}

J. C. N. Coulston, "Late Roman military equipment culture," in: War and Warfare in Late Antiquity: Current Perspectives (ed. N. Christie), Leiden 2010, 463-492.

\section{DELBRÜCK 1964}

Hans Delbrück, Geschichte der Kriegskunst im Rahmen der politischen Geschichte, Berlin 1964.

DRAKE 2006

H. A. Drake (ed.), Violence in late antiquity, Aldershot 2006.

\section{DREW-BEAR 1977}

Thomas Drew Bear, "A Fourth century Latin's soldier epitaph from Nakolea," Harvard Studies in Classical Philology, 81, Cambridge, MA $1977,257-275$

\section{ELTON 1986.}

Hugh Elton, "Fravitta and barbarian career opportunities in Constantinople," Medieval Prosopography, 17, Kalamazoo, MI 1986, 95106.

\section{ELTON 1996}

Hugh Elton, Warfare in Roman Europe, AD 350-425, Oxford 1996.

\section{GLEASON 1995}

Maud W. Gleason, Making Men: Sophists and Self-Presentation in Ancient Rome, Princeton 1995.

\section{GOLDSWORTHY 1999}

Adrian Goldsworthy, lan Haynes and C. E. P. Adams, The Roman army as a community, Portsmouth 1999.

HALSALL 2004

Guy Halsall, "Gender and the End of Empire," Journal of Medieval and Early Modern Studies, 34/1, Durham 2004, 17-40.

HALSALL 2007

Guy Halsall, Barbarian migrations and the Roman West, 376-568, Cambridge 2007. 
40 |

\section{HEATHER 1999}

Heather, Peter, "The Barbarian in Late Antiquity. Image, reality, and transformation," in:, Constructing Identities in Late Antiquity (ed. R. Miles), London and New York 1999, 234-258.

\section{HEATHER 1996}

Peter Heather, The Goths, Oxford 1996.

\section{HOFFMAN 1963}

Dietrich Hoffmann, "Die spätrömischen Soldatengrabschriften von Concordia," in: Museum Helveticum, 20, Zurich 1963, 22-57.

\section{HOFFMAN 1970}

Dietrich Hoffmann, Das spatromische bewegungsheer und die notitia dignitatum, Dusseldorf 1970.

HOSS 2011

Stefanie Hoss, "The Roman military belt," in: Wearing the Cloak: Dressing the Soldier in Roman Times (eds. M. L. Nosch and H. Koefoed), Oxford 2011, 29-44.

\section{JONES 1964}

A. H. M Jones, The later Roman empire 284- 602. A social, economic and administrative survey, Oxford 1964.

\section{KULIKOWSKI 2000}

Michael Kulikowski, "The Notitia Dignitatum as a Historical Source," Historia, 49/3, Stuttgart 2000, 358-377.

\section{LADNER 1976}

Gerhart B. Ladner, "On Roman Attitudes toward Barbarians in Late Antiquity," Viator, 7, Berkeley 1976, 1-26.

LEE 1993

A. D. Lee, Informations and Frontiers: Roman Foreign relations in Late Antiquity, Cambridge 1993.

\section{LEE 2007}

A. D. Lee, War in late antiquity. A social history, Malden 2007.

LENSKI 2002

Noel Lenski, Failure of Empire: Valens and the Roman State in the Fourth Century A.D., Berkeley 2002. 


\section{MACMULLEN 1988}

Ramsay MacMullen, Corruption and the decline of Rome, New Haven 1988.

\section{MATHISEN 2006a}

Ralph Mathisen, "Peregrini, Barbari, and Cives Romani: Concepts of Citizenship and the Legal Identity of Barbarians in the Later Roman Empire," The American Historical Review, 111/4, Bloomington 2006, 1011-1040.

\section{MATHISEN 2006b}

Ralph Mathisen, "Violent Behavior and the Construction of Barbarian identity in late Antiquity, in: H. A. Drake (ed.), Violence in late Antiquity, Aldershot 2006, 27-35.

\section{MATHISEN AND SHANZER 2011}

Ralph Mathisen, Danuta Shanzer (eds.), Romans, barbarians, and the transformation of the Roman world, Farnham 2011.

\section{MATTHEWS 1975}

John Matthews, Western aristocracies and imperial court AD. 364-425, Oxford 1975.

\section{MCCORMICK 1986}

Michael McCormick, Eternal Victory: Triumphal Rulership in Late Antiquity, Byzantium, and the Early Medieval West, Cambridge: 1986.

MILES 2002

Richard Miles, Constructing identities in late antiquity, London 2002.

\section{NICASIE 1998}

Martinus Johannes Nicasie, Twilight of empire: The Roman army from the reign of Diocletian until the Battle of Adrianople, Amsterdam 1998.

\section{NOSCH 2012}

Marie-Louise Nosch, Wearing the Cloak: Dressing the Soldier in Roman Times, Oxford 2012.

\section{PETERSEN 2013}

Leif I. R. Petersen, Siege warfare and military organization in the successor states, Leiden 2013.

POHL 1998

Walter Pohl, "Concepts of ethnicity in early medieval studies," in: Debating the Middle Ages: Issues and Readings (eds. L. K. Little and B. H. Rosenwein), Malden 1998. 
42 |

ROCCO 2012

Marco Rocco, L'esercito romano tardoantico. Persistenze e cesure dai Severi a Teodosio I, Padova 2012.

\section{SANDERS 1939}

Erich Sanders, "Die germanisierung des römischen Heeres," Historische Zeitschrift, 160, Frankfurt 1939, 1-34.

SHAW 1984

Brent D. Shaw, "Bandits in the Roman Empire," Past and Present, 105/1, Oxford 1984, 3-52.

\section{SOUTHERN AND DIXON 1996}

Pat Southern and K. R. Dixon, The Late Roman Army, London 1996.

SPEIDEL 1994

Michael Speidel, Riding for Caesar: The Roman Emperors' Horse Guard, Cambridge 1994.

STOURAITIS 2014

Ioannis Stouraitis, "Roman identity in Byzantium: a critical approach," Byzantinische Zeitschrift 107/1, Vienna 2014.

WILLIAMS AND FRIELL 1998

Stephen Williams and Gerard Friell, Theodosius: The Empire at bay, London 1998.

WHITBY 2006

Michael Whitby, "Emperors and Armies, AD 235-395," in: Approaching Late Antiquity: The Transformation from Early to Late empire (eds. S. Swain and M. Edwards), Oxford 2006, 156-186.

WHITTAKER 1994

C. R. Whittaker, Frontiers of the Roman Empire, Baltimore 1994.

WOODWARD 1997

Kathryn Woodward, Identity and difference, London 1997. 